DOI 10.22460/jpmi.v1i3.239-248

\title{
ANALISIS KEMAMPUAN BERPIKIR KREATIF MATEMATIS SISWA SMP PADA MATERI BANGUN RUANG
}

\author{
Muhamad Arfan Andiyana', Rippi Maya ${ }^{2}$, Wahyu Hidayat ${ }^{3}$ \\ 1,2,3 IKIP Siliwangi, Jl. Terusan Jenderal Sudirman, Cimahi, Jawa Barat, Indonesia \\ ${ }^{1}$ arfanandiyana04@ gmail.com, ${ }^{2}$ rippimaya@gmail.com, ${ }^{3}$ wahyu@ikipsiliwangi.ac.id
}

Diterima: 18 Maret 2018; Disetujui: 28 Mei 2018

\begin{abstract}
This study aims to determine the ability to think creatively mathematically junior high school students in Ngamprah village with indicators of students' mathematical creative thinking ability used is fluency (fleuncy), flexibility, originality and elaboration. the ability to think mathematically creative is the ability to think that aims to create or find new ideas that are different, unusual, original that brings definite and precise results. This research was conducted to 33 students in one of Junior High School in Ngamprah Village by using qualitative descriptive method. Instrument used in the form of 5 items about the ability of students' mathematical creative thinking on the matter of building a flat side room with interviews to students. The conclusion of this research is the ability of mathematical creative thinking of junior high school students in Ngamprah village is still very low.
\end{abstract}

Keywords: Mathematical Creative Thinking, Geometry

\begin{abstract}
Abstrak
Penelitian ini bertujuan untuk mengetahui kemampuan berpikir kreatif matematis siswa SMP di Desa Ngamprah dengan indikator kemampuan berpikir kreatif matematis siswa yang digunakan adalah kelancaran (fleuncy), kelenturan (flexibility), keaslian (originality) dan elaborasi (elaboration). kemapuan berpikir kreatif matematis adalah kemampuan berpikir yang bertujuan untuk menciptakan atau menemukan ide baru yang berbeda, tidak umum, orisinil yang membawa hasil yang pasti dan tepat. Penelitian ini dilakukan kepada 33 siswa di salah satu SMP di Desa Ngamprah dengan menggunakan metode deskriptif kualitatif. Instrumen yang digunakan berupa 5 butir soal kemampuan berpikir kreatif matematis siswa pada materi bangun ruang sisi datar disertai wawancara kepada siswa. Kesimpulan dari penelitian ini adalah kemampuan berpikir kreatif matematis siswa SMP di Desa Ngamprah masih sangat rendah.
\end{abstract}

Kata Kunci: Berpikir Kreatif Matematis, Geometri

How to cite: Andiyana, M. A., Maya, R., \& Hidayat, W. (2018). Analisis Kemampuan Berpikir Kreatif Matematis Siswa SMP pada Materi Bangun Ruang. JPMI - Jurnal Pembelajaran Matematika Inovatif, 1 (3), 239-248.

\section{PENDAHULUAN}

Matematika merupakan salah satu bagian yang penting dalam bidang ilmu pengetahuan. Apabila dilihat dari sudut pengklasifikasian bidang ilmu pengetahuan, matematika termasuk ke dalam ilmu-ilmu eksakta yang lebih banyak memerlukan berpikir kreatif dari pada hapalan.(Arifin \& Purwasih, 2017).

Menurur Hamalik (2013),'Pendidikan merupakan suatu proses dalam rangka mempengaruhi peserta didik supaya mampu menyesuaikan diri sebaik mungkin dengan lingkungannya, dan 
dengan demikian akan menimbulkan perubahan dalam dirinya yang memungkinkannya untuk berfungsi secara adekawat dalam kehidupan masyarakat". Selain itu juga pendidikan merupakan salah satu aspek dalam kehidupan yang memegang peranan penting. Suatu negara dapat mencapai sebuah kemajuan dalam teknologinya, jika pendidikan dalam negara kualitasnya baik. Tinggi rendahnya kualitas pendidikan di pengaruhi oleh banyak faktor. Faktor yang mempengaruhi pendidikan formal yang berada di sekolah bisa berasal dari siswanya, pengajarnya, sarana prasarananya, dan bisa juga karena faktor lingkungannya.

Keratif menurut kamus besar bahasa indonesia ialah memiliki daya cipta atau memiliki kemampuan untuk menciptakan, sedangkan matematis ialah sangat pasti dan tepat. Sehingga dapat diartikan kemapuan berpikir kreatif matematis adalah kemampuan berpikir yang bertujuan untuk menciptakan atau menemukan ide baru yang berbeda, tidak umum, orisinil yang membawa hasil yang pasti dan tepat. Kehidupan yang semakin modern seperti saat ini kemampuan berpikir setiap manusia harus pula semakin modern, terlebih dalam kemampuan berpikir matematis. Karna matematika adalah suatu ilmu yang dapat mencakup segala aspek dalam kehidupan dan pendidikan. Selain berpikir kreatif matematis berpikir kreatif dalam bidang lainnya juga diperlukan seperti yang dikemukakan (Nurmasari, Kusmayadi., \& Riyadi. 2014). Berpikir kreatif dalam matematika dan dalam bidang lainnya merupakan bagian keterampilan hidup yang perlu dikembangkan terutama dalam menghadapi era informasi dan suasana bersaing semakin ketat. Individu yang diberi kesempatan berpikir kreatif akan tumbuh sehat dan mampu menghadapi tantangan. Sebaliknya, individu yang tidak diperkenankan berpikir kreatif akan menjadi frustrasi dan tidak puas.

Masalah-masalah yang dihadapi seseorang akan menjadi lebih kompleks seiring perkembangan usia dan lingkungan sosialnya. Untuk dapat survive, seseorang perlu memiliki kemampuan berpikir kritis dan kreatif, karena dengan memiliki kemampuan tersebut ia akan lebih mudah menghadapi masalah dan menyelesaikannya (Happy \& Widjajanti, 2014). Untuk itu, manusia dituntut memiliki kemampuan dalam memperoleh, memilih, mengelola, dan menindaklanjuti informasi itu untuk dimanfaatkan dalam kehidupan yang dinamis, sarat tantangan, dan penuh kompetisi. Ini semua menuntut kita memiliki kemampuan berpikir kritis, kreatif, logis, dan sistematis (Herman, 2007; Hidayat, 2011). Maka Kemampuan berpikir, baik berpikir kritis maupun berpikir kreatif merupakan kemampuan yang penting untuk dimiliki siswa agar siswa dapat memecahkan persoalan-persoalan yang dihadapi dalam dunia yang senantiasa berubah. Dengan demikian, pengembangan kemampuan berpikir, baik berpikir kritis maupun berpikir kreatif merupakan suatu hal yang penting untuk dilakukan dan perlu dilatihkan pada siswa mulai dari jenjang pendidikan dasar sampai jenjang pendidikan menengah. (Dilla, Hidayat, \& Rohaeti, 2018; Hidayat, 2012; Istianah, 2013).

Pentingnya mempelajari matematika dalam menata kemampuan berpikir para siswa, bernalar, memecahkan masalah, berkomunikasi, mengaitkan materi matematika dengan keadaan sesungguhnya, serta mampu menggunakan dan memanfaatkan teknologi. salah satu tujuan yang perlu dicapai dalam pembelajaran matematika adalah kemampuan siswa dalam berpikir kreatif matematis. Karena berpikir kreatif secara umum dalam matematika merupakan bagian keterampilan hidup yang sangat diperlukan siswa dalam menghadapi kemajuan IPTEKS yang semakin pesat serta tantangan, tuntutan dan persaingan global yang semakin pesat.

Penelitian ini dilakukan bertujuan untuk mengetahui sejauh mana kemampuan berpikir kreatif matematis siswa SMP di desa Ngamprah, karena menurut Sumarmo, Hidayat, Zukarnaen, Hamidah, \& Sariningsih, (2012) mengemukakan bahwa agar menjadi pemikir kreatif sebagai berikut: 
a. Bekerja dengan kemampuan tinggi, dengan cara percaya diri yang kuat, dan merasa tertantang untuk menyelesaikan masalah meskipun belum menguasainya dengan baik.

b. Mempertimbangkan ide sendiri dari sudut pandang yang lain sehingga ditemukan idea yang lebih baik.

c. Mengerjakan semua tugas dengan didasari motif internal dan bukan karena motif eksternal, bersifat proaktif, dan tidak menjadi individu yang reaktif.

d. Berpikir secara divergen, mampu mempertimbangkan sesuatu dari dari sudut pandang yang berbeda, mengajukan berbagai alternatif solusi.,bersikap terbuka dan fleksibel.

e. Berpikir lateral, imajinatif, tidak hanya dari tampak tapi juga dari yang tak tampak, dan berpikir vertikal. Berpikir lateral adalah melihat permasalahan dari beberapa sudut baru, seolah-olah melompat dari satu tangga ke tangga lainnya. Namun dengan berpikir lateral akan mampu berpikir generatif dan provokatif, dan memperoleh idea yang lebih bagus. Berpikir vertikal adalah suatu proses bergerak selangkah demi selangkah menuju suatu tujuan, seolah-olah sedang menaiki tangga. Melalui berpikir vertikal individu dapat berpikir melompat, namun dengan berpikir lateral.

Dalam pembelajarannya menurut Sugilar (2013). Kemampuan berpikir kreatif siswa tidak dapat berkembang dengan baik apabila dalam proses pembelajaran guru tidak melibatkan siswa secara aktif dalam pembentukan konsep, metode pembelajaran yang digunakan di sekolah masih secara konvensional, yaitu pembelajaran yang masih berpusat pada guru. Pembelajaran tersebut dapat menghambat perkembangan kreatifitas dan aktifitas siswa seperti dalam hal mengkomunikasikan ide dan gagasan. Sehingga keadaan ini tidak lagi sesuai dengan target dan tujuan pembelajaran matematika. Tujuan pembelajaran akan tercapai apabila perencanaan dan metode yang digunakan dapat mempengaruhi potensi dan kemampuan yang dimiliki peserta didik dan keberhasilan tersebut akan tercapai apabila peserta didik dilibatkan dalam proses berpikirnya.

Berdasarkan uraian diatas maka dapat ditarik kesimpulan bahwa kemampuan berpikir kreatif adalah kemampuan siswa menarik kesimpulan dari suatu permasalahan matematika melalui langkah langkah yang tidak rutin. Dengan berpikir kretif peserta didik mampu melakukan berbagai hal untuk menyelesaikan konsep matematika dengan sudut pandang yang berbedabeda.

Dari pernyataan diatas maka indikator yang penulis pakai untuk penelitian adalah Kelancaran (fluency), Kellenturan (flexibility), Keaslian (originality),Elaborasi (elaboration). Penelitian ini bertujuan untuk mengetahui kemampuan berpikir kreatif matematis siswa SMP di desa Ngamprah.

\section{METODE}

Penelitian ini merupakan penelitian deskriptif kualitatif. Subjek dalam penelitian ini adalah 33 orang siswa kelas IX salah satu SMP di desa Ngamprah kabupaten Bandung Barat. Waktu penelitian ini diadakan pada semester genap tahun ajaran 2017-2018. Teknik pengumpulan data dalam penelitian ini menggunakan instrumen tes kemampuan berpikir kreatif. Pemilihan subjek dengan melakukan wawancara kepada siswa tentang pelajaran matematika dan materi yang akan di ajarkan berdasarkan berbagai pertimbangan tersebut, ditentukan 6 orang subjek penelitian. Instrumen yang digunakan berupa soal uraian tes kemampuan berpikir kreatif matematik siswa. 


\section{HASIL DAN PEMBAHASAN}

\section{Hasil}

Penelitian ini dilaksanakan pada salah satu kelas IX di salah satu SMP negeri yang ada di Desa Ngamprah Bandung Barat. Data dari hasil penelitian ini yaitu berupa hasil belajar siswa yang pengumpulan datanya menggunakan instrumen soal tes berupa uraian sebanyak 5 soal. Data tes diperoleh dari analisis jawaban siswa berdasarkan acuan pedoman penskoran kemampuan berpikir kreatif matematis. Mendeskripsikan kemampuan berpikir kreatif matematis siswa dalam menyelesaikan soal pada materi bangun ruang pada tiap soal. Pada penelitian ini meliputi Kelancaran (fluency), Kelenturan (flexibility), Keaslian (originality), Elaborasi (elaboration).

Tabel 1. Deskripsi indikator kelancaran (fluency)

\begin{tabular}{cc}
\hline Kode Siswa & Jumlah Skor \\
\hline 001 & 3 \\
002 & 3 \\
003 & 2 \\
004 & 2 \\
005 & 2 \\
006 & 2 \\
Jumlah & 14 \\
Persentase $(\%)$ & $56,3 \%$ \\
\hline
\end{tabular}

Berdasarkan Tabel 1 tersebut menujukan kemampuan berpikir lancar (fluency) pada soal nomor 1 dengan presentase $56,3 \%$.

Tabel 2. Deskrpisi indikator kelenturan (flexibility)

\begin{tabular}{cc}
\hline Kode Siswa & Jumlah Skor \\
\hline 001 & 4 \\
002 & 4 \\
003 & 4 \\
004 & 3 \\
005 & 3 \\
006 & 3 \\
Jumlah & 21 \\
Persentase $(\%)$ & $87,5 \%$ \\
\hline
\end{tabular}

Berdasarkan Tabel 2 tersebut menunjukan kemampuan berpikir lentur (flexibility) pada soal nomor 2 dengan presentase $87,5 \%$. 
Tabel 3. Dekripsi indikator Elaborasi (elaboration)

\begin{tabular}{cc}
\hline Kode Siswa & Jumlah Skor \\
\hline 001 & 2 \\
002 & 2 \\
003 & 2 \\
004 & 2 \\
005 & 2 \\
006 & 2 \\
Jumlah & 12 \\
Persentase $(\%)$ & $50 \%$ \\
\hline
\end{tabular}

Berdasarkan Tabel 3 tersebut menunjukan kemampuan elaborasi pada soal nomor 3 dengan presentase $50 \%$.

Tabel 4. Deskripsi indikator Keaslian (originality)

\begin{tabular}{ccc}
\hline Kode Siswa & Jumlah Skor & Jumlah Skor \\
\hline 001 & 2 & 1 \\
002 & 2 & 1 \\
003 & 2 & 1 \\
004 & 2 & 0 \\
005 & 2 & 0 \\
006 & 2 & 0 \\
Jumlah & 12 & 3 \\
Persentase $(\%)$ & $50 \%$ & $12,5 \%$ \\
\hline
\end{tabular}

Berdasarkan Tabel 4 tersebut menunjukan kemampuan berpikir keaslian (originality) pada soal nomor $4-5$ dengan presentase $50 \%$ \& $12,5 \%$

\section{Pembahasan}

Melihat rata-rata presentase dari semua indikator hanya ada 1 indikator yang melebihi $50 \%$ yaitu pada indikator kelenturan sebanyak $87,5 \%$, dapat dikatakan rata-rata kemampuan berpikir kreatif siswa masih rendah.

\section{Soal no 1}

Sebuah balok memiliki volume $384 \mathrm{~cm}^{3}$, carilah kemungkinan-kemungkinan dari ukuran panjang, lebar dan tinggi rusuk balok tersebut, minimal 2 ukuran!

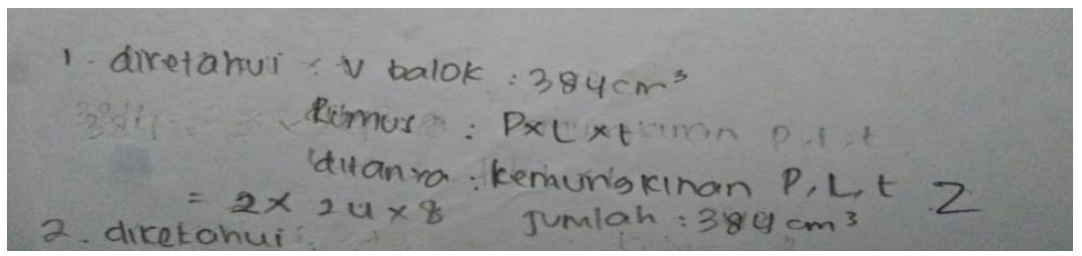

Gambar 1. Jawaban Siswa Soal No 1 
Dari jawaban siswa pada gambar 1 dia menjawab hanya satu ukuran sedangkan pada soal diminta 2 ukuran. Dari semua sampel mereka menjawab dengan ukuran yang berbeda tapi masing-masing hanya menjawab satu ukuran saja, karna siswa kurang teliti padahal jelas pada soal terdapat perintah untuk menyebutkan dua ukuran. Pada indikator soal (fluency) ini ratarata presentase siswa mencapai 56,3\% menandakan sebagian siswa mampu menjawab pertanyaan dengan benar. Berdasarkan hasil wawancara mereka dapat menybutkan ukuran yang lainnya selain dari yang mereka tuliskan hanya saja mereka menyebut bahwa kurang teliti dalam membaca soal.

\section{Soal no 2}

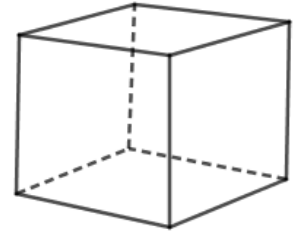

A

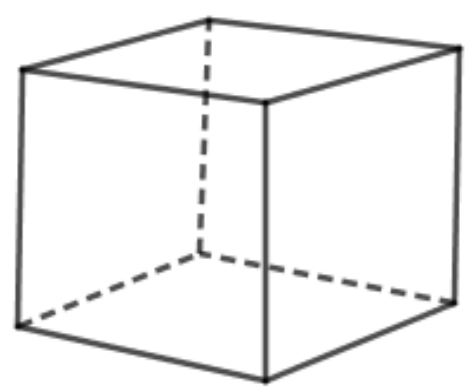

B

Perbandingan volume dua buah kubus tersebut adalah 3:7 jika kubus $B$ di isi oleh beberapa kubus A, tentukan berapa banyak kubus A yang diperlukan untuk memenuhi kubus B. Apabila ada sisa ruang maka berapakah sisanya?

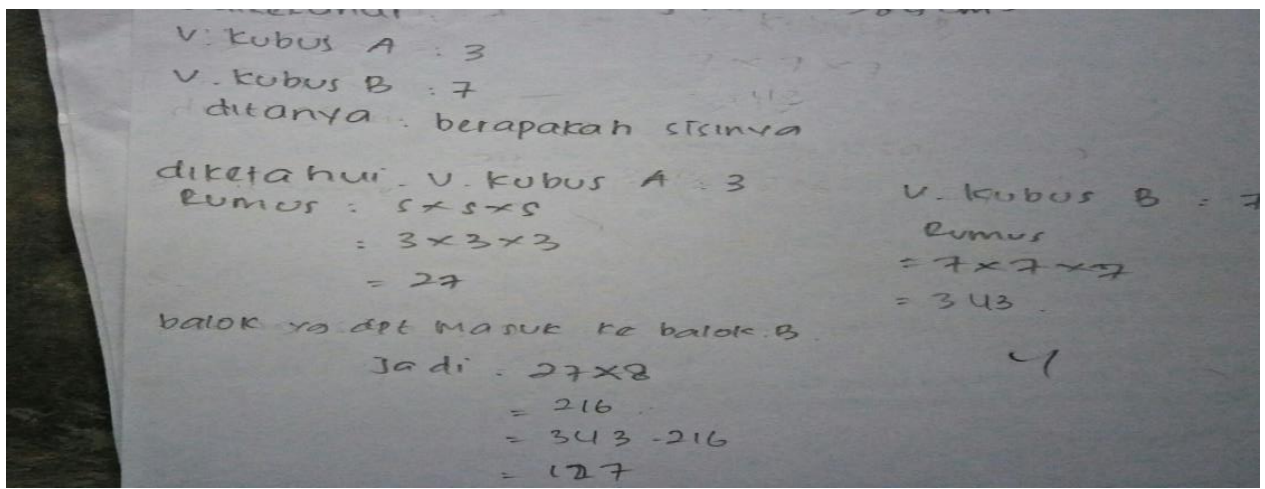

Gambar 2. Jawaban Siswa Soal No 2

Jawaban siswa pada soal nomor 2 sangat baik dimana dia menghitung masing-masing volume balok dengan memisalkan panjang rusuk masing-masing balok. Pada indikator soal (flexibility) ini siswa rata-rata mencapai presentase sebesar 87,5\% yang menandakan kemampuan siswa menjawab soal dengan indikator flexibility cukup tinggi . Berdasarkan hasil wawancara dengan siswa tersebut dia menjelaskan bahwa apabila dapat menemukan perbandingan rusuknya dengan tepat maka akan mudah menjawab berapa masing-masing 
balok, akan tetapi untuk mengetahui jumlah balok A yang dapat masuk kedalam kubus B menurutnya memerlukan ketelitian dan pengamatan yang tepat.

\section{Soal 3}

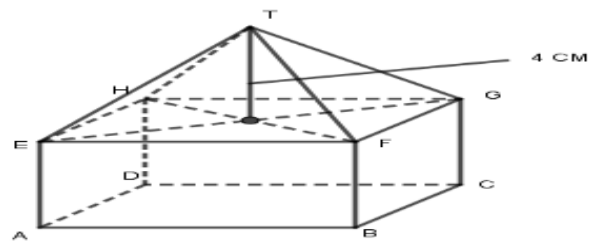

Sebuah prisma persegi panjang ABCD.EFGH memiliki atap dengan tinggi $4 \mathrm{~cm}$, panjang rusuk $A B=6 \mathrm{~cm}, B C=4 \mathrm{~cm}, C G=3 \mathrm{~cm}$ serta $T F=5 \mathrm{~cm}$, jelaskan secara rinci cara menghitung luas permukaan prisma persegi panjang tersebut.

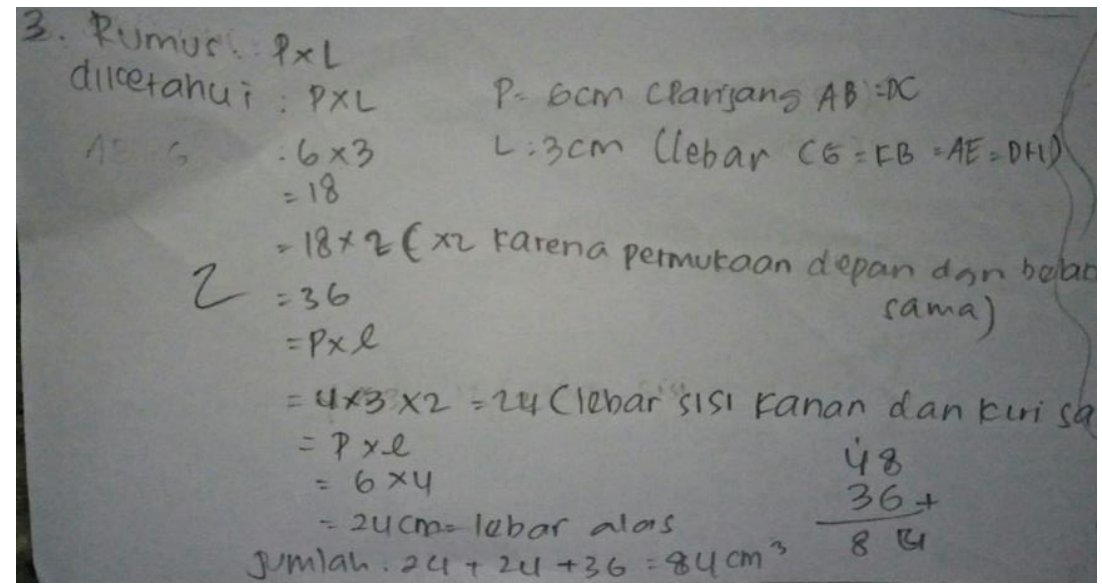

Gambar 3. Jawaban Siswa Soal No 2

Jawaban siswa pada gambar 3 menunjukan siswa hanya mampu menjawab luas permukaan prisma persegi panjang saja namun mereka tidak dapat menemukan luas perkmukaan limasnya. Pada indikator soal (elaborasi) ini siswa mampu menjawab dengan rata-rata presentase sebesar 50\% ini menandakan kemampuan siswa pada menjawab soal indikator ini rendah. Berdasrakan hasil wawancara dengan siswa tersebut dia menjelaskan bahwa lupa untuk menghitung luas permukaan sebuah limas.

\section{Soal 4}

Diketahui sebuah limas segi empat mempunyai volume $192 \mathrm{~cm}^{3}$. Tentukanlah ukuran panjang, lebar serta tinggi tersebut dengan caramu sendiri! Kemudian hitunglah luas permukaan limas segi empat tersebut! 


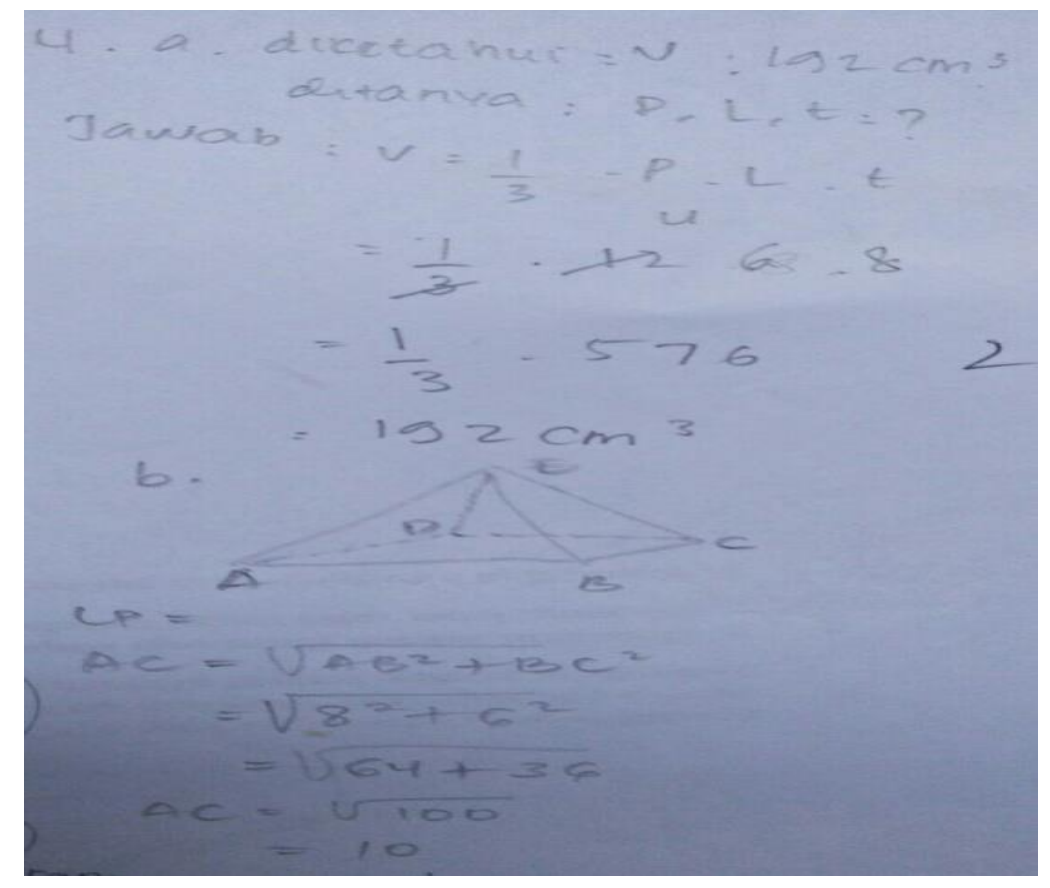

Gambar 4. Jawaban Siswa Soal No 4

Jawaban siswa dari gambar 4 siswa dapat menemukan ukuran sebuah limas tersebut hanya saja dia tidak dapat menemukan luas permukaannya. Pada indikator soal (originality) ini siswa mampu menjawab dengan rata-rata presentase sebesar 50\% dan $12,5 \%$ ini menandakan kemampuan siswa pada menjawab soal indikator ini sangat rendah. Berdasarkan hasil wawancara dengan siswa terebut menjelaskan bahwa dia juga sama tidak dapat menemukan luas permukaan tersebut karna tidak mengetahui rumus luas permukaan sebuah limas.

\section{KESIMPULAN}

Berdasarkan penelitian kemampuan berpikir kreatif matematis siswa SMP di Desa Ngamprah pada materi bangun ruang masih sangat rendah. Dengan melihat rata-rata presentase sebesar $51 \%$.Adapun presentasenya sebagai berikut untuk indikator flexibility merupakan yang tertinggi yaitu $87,5 \%$ menandakan sebagian siswa mampu berpikir lancar dalam mngerjakan soal, indikator fluency $56,3 \%$, indikator elaborasi $50 \%$ dan dan yang paling rendah yaitu pada infikator originality $50 \%$ serta $12,5 \%$. Pada soal indikator originality ini siswa tidak mampu memberikan jawaban apa yang diingikan, hal ini disebabkan karna siswa tidak mampu menemukan luas permukaan limas, dimana tahapannya menemukan sisi tegak segitiga tetapi siswa lupa dan tidak tau rumus tersebut.

\section{DAFTAR PUSTAKA}

Aripin, U. Purwasih, R. (2017). Penerapan Pembelajaran Berbasis Alternative Solutions Worksheet untuk Meningkatkan Kemampuan Berpikir Kreatif Matematik. Jurnal Pendidikan Matematika FKIP Univ. Muhammadiyah Metro Vol. 6, No. 2.

Dilla, S. C., Hidayat, W., \& Rohaeti, E. E. (2018). Faktor Gender dan Resiliensi dalam Pencapaian Kemampuan Berpikir Kreatif Matematis Siswa SMA. Journal of Medives, 2(1), 129-136. 
Hamalik, O. (2013). Kurikulum dan Pembelajaran. Jakarta: Pusat Penerbit PT Bumi Aksara.

Happy, N., \& Widjajanti, D, B. (2014). Keefektifan PBL Ditinjau dari Kemampuan Berpikir Kritis dan Kreatif Matematis Self-Esteem Siswa SMP. Jurnal Riset Pendidikan Matematika, Volume 1, Nomor 1

Herman, T. (2007). Pembelajaran Berbasis Masalah untuk Meningkatkan Kemampuan Berpikir Matematis Tingkat Tinggi Siswa Sekolah Menengah Pertama. Jurnal EDUCATIONIST No. I Vol. I.

Hidayat, W. (2011). Meningkatkan Kemampuan Berpikir Kritis dan Kreatif Matematik Siswa Melalui Pembelajaran Kooperatif Think-Talk-Write (TTW) (Doctoral dissertation, Universitas Pendidikan Indonesia).

Hidayat, W. (2012). Meningkatkan Kemampuan Berpikir Kritis dan Kreatif Matematik Siswa SMA Melalui Pembelajaran Kooperatif Think-Talk-Write (TTW). In Seminar Nasional Penelitian, Pendidikan dan Penerapan MIPA.

Istinah, E. (2013). Meningkatkan Kemampuan Berpikir Kritis dan Kreatif Matematik dengan Pendekatan Model Elicing Activies (MEAs) Pada Siswa SMA. InfinityJurnal Ilmiah Program Studi Matematika STKIP Siliwangi Bandung, Vol 2, No.1

Nurmasari, N. Atmojo, T., \& Riyadi. (2014). Analisis Berpikir Kreatif Siswa dalam Menyelasaikan Masalah Matematika pada Materi Peluang Ditinjau dari Gender Siswa Kelas XI IPA SMA Negeri 1 Kota Banjarbaru Kalimantan Selatan. Jurnal Elektronik Pembelajaran Matematika ISSN: 2339-1685 Vol.2, No.4, hal 351 - 358

Sugilar, H. (2013). Meningkatkan Kemampuan Berpikir Kreatif dan Disposisi Matematik Siswa Madrasah Tsanawiyah Melalui Pembelajaran Generatif. InfinityJurnal Ilmiah Program Studi Matematika STKIP Siliwangi Bandung, Vol 2, No.2.

Sumarmo, U., Hidayat, W., Zukarnaen, R., Hamidah, M., \& Sariningsih, R. (2012). Kemampuan dan Disposisi Berpikir Logis, Kritis, dan Kreatif Matematik (Eksperimen terhadap Siswa SMA Menggunakan Pembelajaran Berbasis Masalah dan Strategi Think-Talk-Write). Jurnal Pengajaran MIPA, 17(1), 17-33. 
248 Andiyana, Maya, \& Hidayat, Analisis Kemampuan Berpikir Kreatif Matematis Siswa ... 